\title{
Effect of restricted suckling time on milk components and sucking behavior of lambs
}

\author{
MURAT CIMEN and MUSA KARAALP \\ Department of Animal Science, Agricultural Faculty, Gaziosmanpasa University, Tokat, Turkey
}

\section{Abstract}

The experiment was conducted to investigate the effects of different suckling systems in non-dairy sheep on the production and components of milk, sucking behavior and lamb growth from day 4 after lambing until the lambs were 4 weeks old. The sixteen ewes with their lambs were used to compare restricted suckling time (R) and free suckling time (F) methods. The $\mathrm{F}$ lambs were maintained with mothers and suckled ad libitum during day. The $\mathrm{R}$ lambs were removed from their dams and allowed to suckle their dams for $15 \mathrm{~min}$ during morning and afternoon period. After two weeks of age, all lambs were encouraged to consume roughage alfa alfa as ad libitum to stimulate their ruminal activity. Daily milk intakes of $R$ lambs were low, while $F$ lambs consumed more milk in 1st and 3 rd weeks. Therefore, $F$ lambs gained more weight in these weeks. The $R$ lambs have been shown to result in lower sucking duration and higher frequency as compared to $F$ lambs until 4th week. There were no significant differences between treatments in change of milk protein during study. However, the milk fat concentrations were higher in the $\mathrm{F}$ group than in $\mathrm{R}$ group until 4th week

Keywords: restricted, free, suckling time, milk components, sucking behavior, lamb

\section{Zusammenfassung}

\section{Der Effekt eingeschränkter Säugezeit auf Milchinhaltsstoffe und Säugeverhalten bei Lämmern}

An 14 nicht Milchschafen wurde der Einfluss unterschiedlicher Säugesysteme auf Milchleistung, -inhaltstoffe, das Säugeverhalten sowie das Lämmerwachstum untersucht. Die Versuchsdauer erstreckte sich vom vierten Lebenstag bis zum Ende der 4. Lebenswoche der Lämmer wobei eine Gruppe der Lämmer eine reduzierte Säugezeit (R) und die andere Gruppe ganztägig einen freien Zugang zu den Müttern hatte (F). Die Lämmer der RGruppe wurden von den Müttern getrennt und erhielten jeweils am Vor- und Nachmittag 15 min Zugang zum Gesäuge der Mütter. Nach einem Alter von 2 Wochen der Lämmer erhielten die Lämmer beider Gruppen Rauhfutter ad libitum. Die Milchaufnahme der RLämmer war geringer als bei den F-Lämmern so dass letztere eine größere Lebenstagszunahme erreichten. Die R-Lämmer zeigten eine kürzere Säugedauer jedoch eine höhere Säugefrequenz. Die Milchinhaltstoffe bei den Müttern beider Gruppen unterschieden sich kaum lediglich der Fettgehalt der F-Gruppe lag signifikant höher.

Schlüsselwörter: Lamm, Säugezeit eingeschränkt, Säugezeit frei, Milchzusammensetzung, Säugeverhalten 


\section{Introduction}

Domestic species are often weaned before natural weaning would occur, and the weaning day is chosen by the farmer for economic reasons, as in the case of piglets and calves (HOUPT and WOLSKI 1982). For a successful weaning, it is necessary that managers understand suckling and nursing behavior, and many studies have been done on suckling behavior of domestic animals (TEH et al. 1987, MAYNTZ et al. 2006). In addition, as efficiency and quality become more and more important today, influences on milk yield and composition must be known.

Two-thirds of the worldks sheep milk production is concentrated in Mediterranean region. Milk from non-dairy sheep is widely used in the Mediterranean and Balkan regions for making cheeses typically consumed in those countries (BOYAZOGLU and MORANDFEHR 2001). Understanding the effective factors on milk components and sucking behavior is a major importance to the sheep industry because the milk and components of it influence the making cheese and the rearing of offspring. One poorly understood factor for milk yields and components is the sucking behavior (SPINKA et al. 1997).

Many studies have been done on suckling behavior of dairy animals (NOWAK et al. 1997, NIZNIKOWSKI et al. 2001). These studies were mainly done on free-range sheep and lambs had free access to suckling. There seems to be few published investigations on the behavior of lambs during restricted suckling period. In restricted sucking treatment, the lambs suffer less stress at weaning. The weaning stress is a big problem for non-dairy sheep breeds. There have been no detailed studies to find out the effect of restricted suckling time on sucking behavior and milk parameters in non-dairy sheep. The aim of this paper is to describe and discuss the effects of different suckling systems in non-dairy sheep on the production and components of milk, suckling behavior and lamb growth.

\section{Material and methods}

The sixteen ewes with their lambs were randomly assigned in equal numbers to two treatments; restricted suckling time (R) and free suckling time (F). All lambs were single born and male. Data were collected from each ewe-lamb pair from day 4 after lambing until the lambs were 4 weeks old. The $\mathrm{F}$ lambs were maintained with mothers and had free access to the mother and suckled ad libitum during day in all weeks. The R lambs were removed from their dams and housed in a separate pen. The lambs in R group were allowed to suckle their dams for 15 min during morning and afternoon suckling period. After two weeks of age, all lambs were encouraged to consume roughage alfa alfa as ad libitum to stimulate their ruminal activity.

The behavior observations were carried out twice daily at 08:00-10:00 and 16:00-18:00 at 7, 14, 21 and 28 days of age. All lambs in both groups were removed from their dams and housed in a separate pen for $14 \mathrm{~h}$ period before observation days and between morning and afternoon observations. On observation days, the observer walked slowly past the front of each pen from a distance of $4 \mathrm{~m}$ and recorded lamb number and sucking behavior of it. The behavior of each lamb was observed for a period of $15 \mathrm{~min}$ in both morning and afternoon observations for normal lambs suck milk from mother in approximately $15 \mathrm{~min}$ (SALLAM 2005). The lambs on both treatments were weighed on 
observation days before and after morning and afternoon suckling in order to determine their milk intake and at the same time serve as a check on their growth rate.

The sucking parameters in Table 1 represent the mean of the morning and afternoon observations. The data recorded during $15 \mathrm{~min}$ observation session were as follows:

Sucking duration: Cumulative duration of sucking bouts throughout the $15 \mathrm{~min}$ observation time. This may include one or several sucking bouts. Sucking bouts are considered successful sucking movements and were timed to the nearest second for the duration of time during which lambs pull at or are in contact with the udder. A sucking bout was considered successful when the lambs' nose was in contact with a female udder for at least $5 \mathrm{~s}$ (SCHAKLETON and HAYWOOD 1985).

Number of sucking bouts (Frequency of sucking): A sucking bout consisted of lamb sucking one or more teats at the udder of the dam.

To determine milk composition, samples were obtained on observation days in all periods by hand-milking before allowing the lambs to nurse. Milk samples were composites of milk collected at consecutive morning and afternoon. The samples were collected into plastic vials preserved with micro tabs, stored $4{ }^{\circ} \mathrm{C}$ until analyzed for determination of total protein and fat. The total protein of the milk was determined by Kjeldahl method (Nx6.38). The milk fat was determined by Roese-Gottlieb Method (HUNDRIESER et al. 1984).

The data concerning intake and parameters of milk and sucking behavior between free and restricted suckling groups were compared by Independent Samples t-test using SPSS software (NORUSIS 1993).

\section{Results and discussion}

The sucking behavior of lambs in $\mathrm{F}$ and $\mathrm{R}$ group is presented in Table 1 . Rearing lambs by $R$ treatment have been shown to result in lower suckling duration and higher frequency as compared to rearing lambs by $\mathrm{F}$ treatment until 4th week. There were no differences between sucking behavior of lambs at last week in $\mathrm{F}$ and $\mathrm{R}$ groups. Probably, shorter duration and higher frequency of sucking in $\mathrm{R}$ lambs was caused by the lower milk secretion and udder-fill rate in their dams. This is consistent with reports that the frequency and duration depend on milk intake and rate of milk withdrawal at each suckling period (FLETCHER 1971) and the decrease in number of daily milking (or suckling) during early lactation results in reduced milk yield in ewes (KNIGHT and GOSLING 1994) because of decreased alveolar diameter (LI et al. 1999) and/or reduced functional udder capacity (NAUMANN 2000, WOJTOWSKI et al. 2006).

Average daily milk intakes were low in $\mathrm{R}$ lambs, while $\mathrm{F}$ lambs suckled more milk in $1 \mathrm{st}$ and 3rd weeks (Table 2). MSKUSICK et al. (2001) observed that milk production drops by 30 to $40 \%$ due to less frequent udder evacuation and lacking of the mother-young bond.

The long-term nursing stimulation of the mammary gland is responsible for the improvement in milk production (HATFIELD et al. 1995). Therefore, the present study concludes that the higher sucking duration is responsible for the increases in milk production of $\mathrm{F}$ sheepp. However, the earlier acceptance of $\mathrm{F}$ lambs by their mother may have positive effect on the ability of the mother to release milk. Because, F dams never 
rejected their lambs' attempts to suck or to explore the udder during the study days or when their lambs were released near them after the separation period in observation days.

Table 1

Mean of sucking behavior in free and restricted suckling time groups during study

Säugeverhalten bei den Versuchsgruppen

\begin{tabular}{lcccc}
\hline & 1st & 2nd & 3rd & Weeks \\
\hline Duration, second & & & & \\
$F$ & $356.25 \pm 9.2$ & $331.25 \pm 10.1$ & $280.0 \pm 16.0$ & $241.3 \pm 8.3$ \\
$R$ & $328.12 \pm 8.7$ & $276.25 \pm 16.0$ & $215.0 \pm 17.8$ & $220.0 \pm 18.4$ \\
$P$ & $*$ & $*$ & & ns \\
Frequency & & & & \\
$F$ & $6.7 \pm 0.2$ & $6.1 \pm 0.3$ & $6.2 \pm 0.2$ & $6.0 \pm 0.3$ \\
$R$ & $7.6 \pm 0.4$ & $6.9 \pm 0.2$ & $6.8 \pm 0.2$ & $6.2 \pm 0.3$ \\
$P$ & $*$ & $*$ & $*$ & ns \\
\hline SE standard error of mean, & $F$ free suckling time, & R & restricted suckling time, ${ }^{*} P<0.05$, & ns not significant
\end{tabular}

Table 2

Mean of milk yields and components and daily gain of lambs in free and restricted suckling time groups during study

Milchaufnahme, Milchzusammensetzung und Lämmertageszunahmen

\begin{tabular}{|c|c|c|c|c|}
\hline & \multicolumn{4}{|c|}{ Weeks } \\
\hline & 1st & 2nd & $3 \mathrm{rd}$ & 4th \\
\hline \multicolumn{5}{|c|}{ Milk intake, g/d } \\
\hline$F$ & $356.30 \pm 5.3$ & $340.0 \pm 8.4$ & $342.5 \pm 7.5$ & $338.8 \pm 6.7$ \\
\hline$R$ & $332.50 \pm 9.5$ & $330.0 \pm 8.0$ & $322.5 \pm 5.3$ & $333.8 \pm 5.9$ \\
\hline P & $*$ & ns & * & $\mathrm{ns}$ \\
\hline \multicolumn{5}{|c|}{ Fat, $\%$} \\
\hline$F$ & $6.5 \pm 0.1$ & $6.3 \pm 0.2$ & $6.2 \pm 0.1$ & $6.0 \pm 0.3$ \\
\hline$R$ & $6.0 \pm 0.2$ & $5.6 \pm 0.2$ & $5.6 \pm 0.2$ & $5.5 \pm 0.2$ \\
\hline P & * & * & * & ns \\
\hline \multicolumn{5}{|c|}{ Protein, \% } \\
\hline$F$ & $5.8 \pm 0.3$ & $5.2 \pm 0.1$ & $5.7 \pm 0.3$ & $5.7 \pm 0.2$ \\
\hline$R$ & $5.9 \pm 0.2$ & $5.5 \pm 0.1$ & $5.6 \pm 0.1$ & $5.6 \pm 0.1$ \\
\hline$P$ & ns & ns & ns & ns \\
\hline \multicolumn{5}{|c|}{ Daily gain, $\mathrm{g} / \mathrm{d}$} \\
\hline$F$ & $350.0 \pm 9.6$ & $315.0 \pm 5.9$ & $331.3 \pm 6.9$ & $341.3 \pm 9.3$ \\
\hline$R$ & $308.7 \pm 16.5$ & $311.2 \pm 14.1$ & $291.3 \pm 16.3$ & $320.0 \pm 9.6$ \\
\hline$P$ & * & ns & * & ns \\
\hline
\end{tabular}

The milk fat concentrations were higher in the $\mathrm{F}$ group than in $\mathrm{R}$ group until 4th week (Table 2). This result may be explained by the fat content of suckled milk increases with increasing suckling time (SANDOVAL-CASTRO et al. 1995). Generally the increase of milk production is associated with a decrease of the milk constituents (HENDERSON and PEAKER 1987), however, total milk fat level in F group was significantly higher. It is also possible that free and frequent suckling (or milking) treatment during day could stimulate local synthesis of the milk fat within the mammary gland (BARNES et al. 1990). It is more probable that frequent milk ejections increased the proportion of fat alveolar 
milk, which increased total milk fat content (KNIGHT and DEWHURST 1994). Some authors (WOLF 2000, CIURYK et al. 2004) suggested that this increase in milk production and milk fat was caused by a metabolic adaptation.

There were no significant differences between treatments in change of milk protein for all periods. Protein percentages are generally similar among different suckling frequencies (SNOWDER and GLIMP 1991).

F lambs gained more weight in 1st and 3rd week. The higher daily gain of the free suckling lambs can be related to their higher milk consumption in these weeks (Table 2). The relationship between lamb growth rate and milk production is strongest from birth to 4 week post partum (TORRES-HERNANDEZ and HOHEN-BOKEN 1980). Increased milk intake is significantly associated with increased weight of offspring (TOUKOUROU and PETES 1999, KORMAN 2001, NIZNIKOWSKI et al. 2006). Higher rates of weight gain and better milk conversion per unit weight gain of the $\mathrm{F}$ lambs in the present study could also be related to the higher fat content in the milk consumed by those lambs compared to the milk consumed by $\mathrm{R}$ lambs and also to the advantages for the digestive tract of young lambs when they suck perpetually and slowly from their dams.

Duration and frequency of sucking in both groups decreased as the age of lamb increased until last week (Figure 1 and 2). This decrease in sucking behavior (duration and frequency) with age of the lambs has been documented by a study done by MANDIKI et al. (1990).

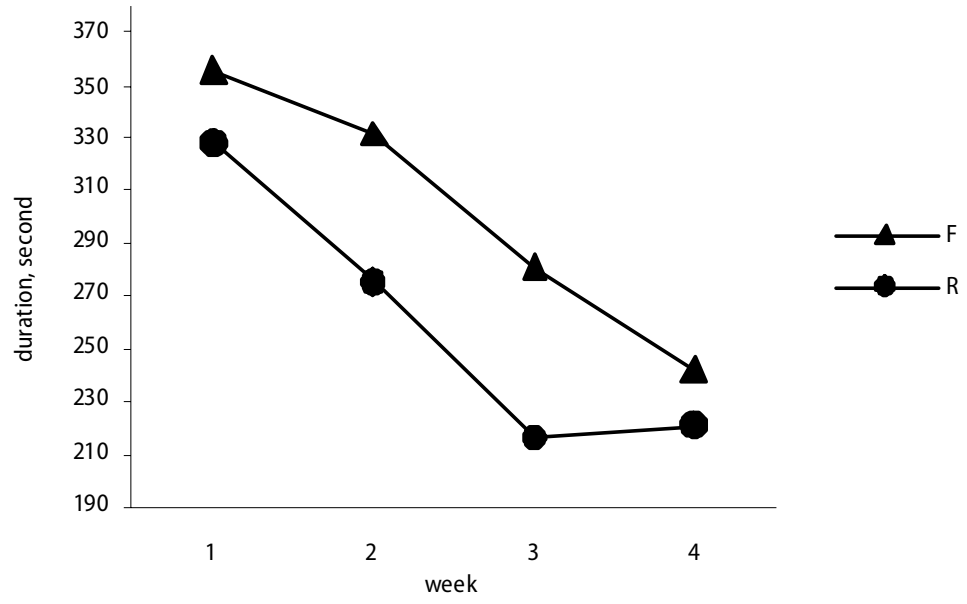

Figure 1

Sucking duration of groups during weeks

Säugedauer

The milk intake curves of both groups were their highest point in first week (Figure 3), which coincided with the maximum milk fat levels (Figure 4) and then declined until last of study. The milk fat curves of both groups were their highest point at the start of lactation, and then declined until last of experiment (Figure 4). This conclusion is in agreement with the observation in same breed that the fat content of sheep milk reaches peak level at the start of lactation then decline until 3rd weeks (CETIN et al. 2007). The highest level of milk fat is usually observed in ruminants at the beginning of the lactation (WOJTOWSKI et al. 2001, HORSTICK and DISTL 2002, VOLANIS et al. 2002). 


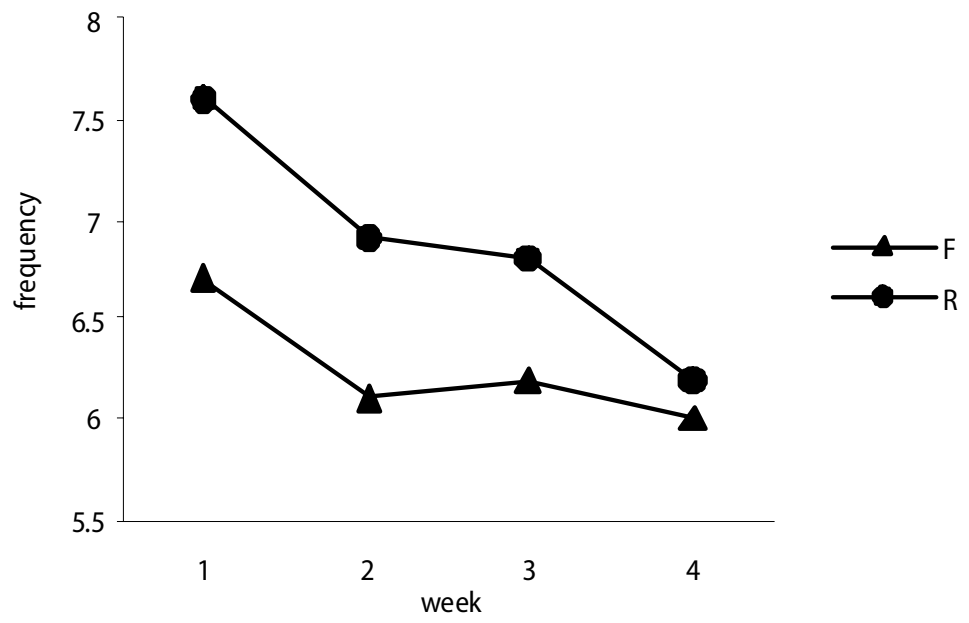

Figure 2

Sucking frequency of groups during weeks

Säugefrequenz

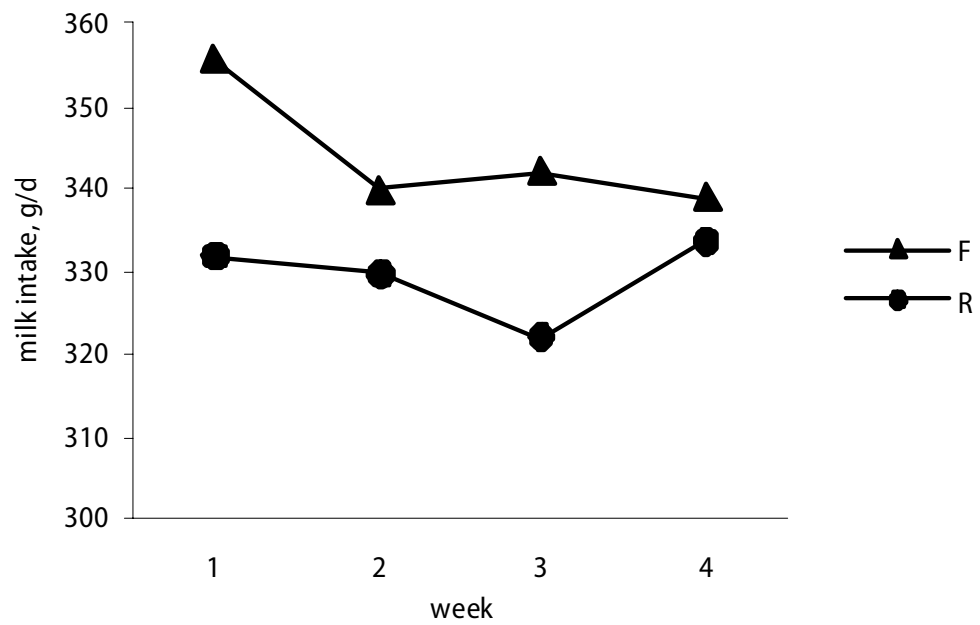

Figure 3

Milk intake of lambs during weeks

Milchaufnahme

The milk protein curves were greatest point in first week, lowest in second week for both groups (Figure 5). Some authors reported that the protein concentration of sheep milk is highest at the first weeks of the lactation (BEDÖ et al. 1997, SCHARCH et al. 2000, NIZNIKOWSKI et al. 2001, HORSTICK and DISTL 2002). 


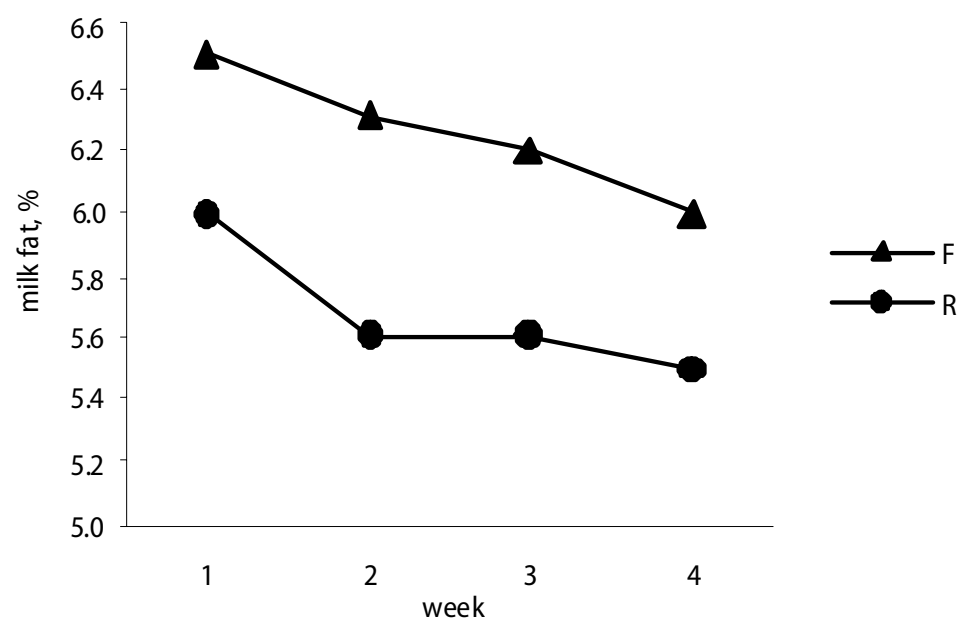

Figure 4

Milk fat of sheep during weeks

Milchfettgehalt

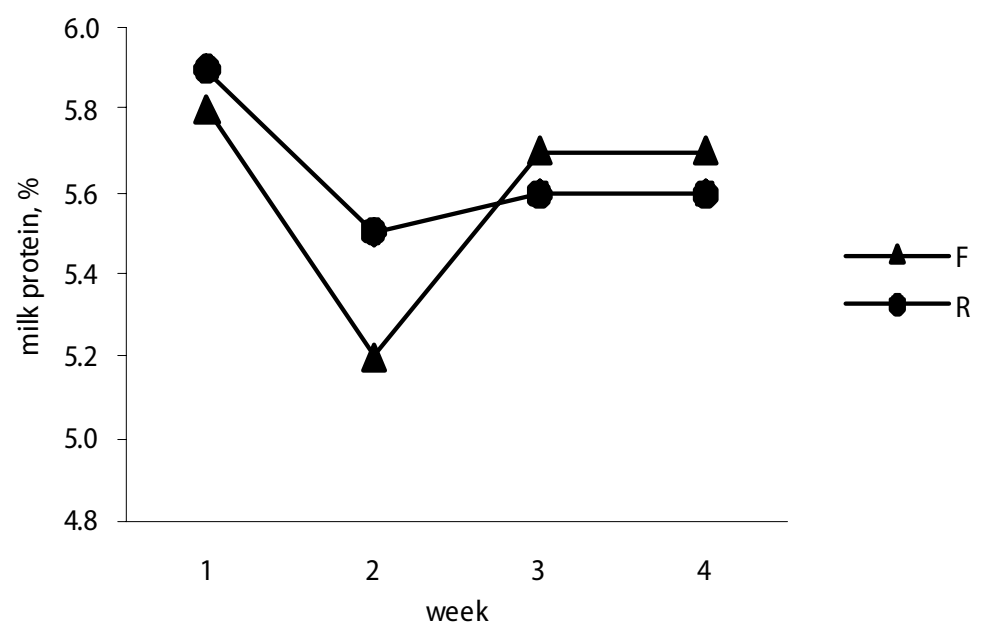

Figure 5

Milk protein of sheep during weeks

Milcheiweißgehalt

In this study, daily gains of the lams of both groups were parallel with milk intakes and milk fat levels during weeks of research (Figure 6). Higher milk intake and milk energy concentrations from fat would contribute to lamb growth. Daily gain of offspring is significantly associated with milk intake (TOUKOUROU and PETES 1999) and milk fat (NIZNIKOWSKI et al. 2006). 


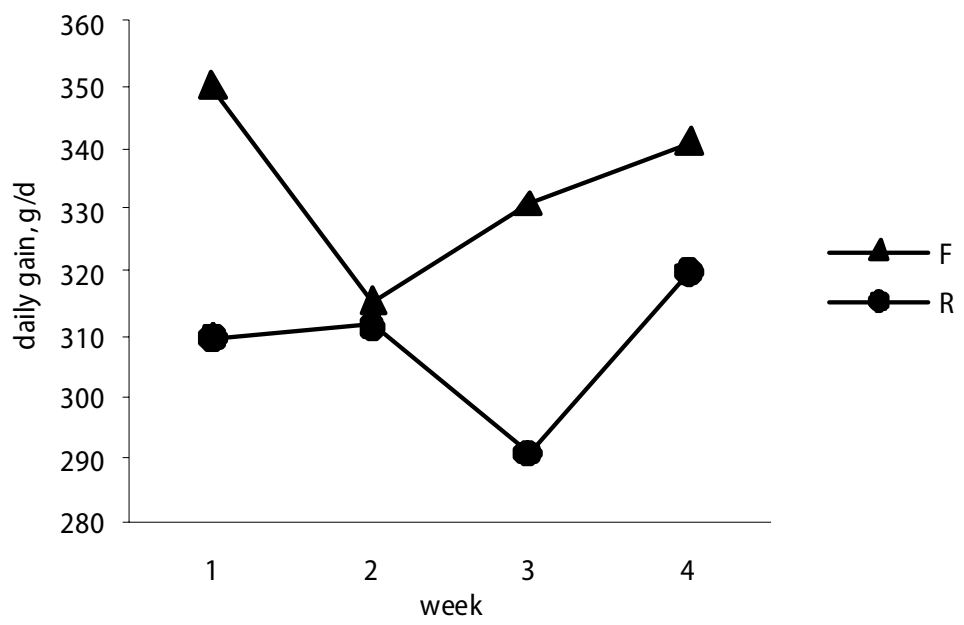

Figure 6

Daily gain of lambs during weeks

Tägliche Zunahme der Lämmer

Results of this study show that restricted suckling time induces fewer values of suckling duration, daily gain, milk intake and fat of milk than the free suckling time system until 4th week. Even though early studies showed the restricted sucking treatment is a wise management approach for dairy cows, this study suggested that restricted sucking time treatment is not suitable for non-dairy ewes.

\section{Acknowledgements}

This study was sponsored jointly by DIMES Ltd., Tokat, Turkey. We like to thank Mr. Ali Riza Diren and Mr. Koray Suner for technical and financial support. We also gratefully acknowledge for friendly cooperating of Rustem UZAMIS who sheep breeder from Songut Village.

\section{References}

Barnes MA, Pearson RE, Lukes-Wilson AJ (1990) Effects of milking frequency and selection for milk yield on productive efficience of Holstein cows. J Dairy Sci 73, 1603-11

Bedö S, Nikodemusz E, Gundel K, Nagy Z (1997) Relations of plasma concentration of urea, glucose and total protein to milk levels of urea, lactose and protein of grazing ewes during lactation. Arch Tierz 40, 265-75

Boyazoglu J, Morand-Fehr P (2001) Mediterranean dairy sheep and goat products and their quality. Small Rum Res 40, 1-11

Cetin M, Cimen M, Dilmac M, Ozgoz E, Karaalp M (2007) Studies of biochemical parameters of milk of sheep milked by machine during early lactation period. Asian J Chem 19, 2135-40

Ciuryk S, Molik E, Kaczor U, Bonczar G (2004) Chemical composition of colostrums and milk of Polish Merino sheep lambing at different times. Arch Tierz 47 SI,129-34

Fletcher IC (1971) Relationship between frequency of suckling, lamb growth and postpartum oestrous behavior in ewes. Anim Behav 19, 108-11 
Hatfield PG, Snowder GD, Head JR WA, Glimp HA, Stobart RH, Beser T (1995) Production by ewes rearing single or twin lambs: Effects of dietary crude protein percentage and supplemental Zinc methionine. J Anim Sci 73, 1227-38

Henderson AJ, Peaker M (1987) Effects of removing milk from the mammary ducts and alveoli or of diluting stored milk, on the rate of milk secretion in the goat. J Exp Phys 72, 13-9

Horstick A, Distl O (2002) Estimation of genetic parameters for test day results of milk performance in East Friesian milk sheep using Bayesian methods for longitudinal data. Arch Tierz 45, 61-8 [in German]

Houpt KA, Wolski TR (1982) Domestic animal behavior for veterinarians and animal scientists. lowa State University. Press, IA, 151-88

Hundrieser KE, Clark RM, Jensen RG, Ferris AM (1984) A Comparison of methods for determination of total lipids in human milk. Nutr Res 4, 21-6

Knight CH, Dewhurst RJ (1994) Once daily milking of dairy cows: relationship between yield loss and cisternal milk storage. J Dairy Res. 61, 441-9

Knight TW, Gosling LS (1994) Effects of milking frequency and machine stripping on milk yields of Dorset ewes. Proc NZ Soc Anim Prod 54, 261-2

Korman K (2001) The effect of feeding system (ad libitum or rationed) on the feed conversion rate and weight gain of Merino ram lambs. Arch Tierz 44 SI, 240-8

Li P, Rudland PS, Ferning DG, Finch LMB, Wilde CJ (1999) Modulation of mammary development and programmed cell death by the frequency of milk removal in lactating goats. J Physiol 519, 885-900

Mandiki SNM, Bister JL, Paquay R (1990) Effects of suckling mode on endocrine control of reproductive activity resumption in Texel ewes lambing in July or November. Theriogenology 33, 397-413

Mayntz M, Sender G, Anderson A, Sederström R (2006) The influence of milk withdrawal, stable routines and separation from dam on Suckling behaviour of Hereford calves. Arch Tierz 49, 545-56

Mskusick BC, Berger YM, Marnet PG, Thomas DL (2001) Effect of two weaning systems on milk composition, storage and ejection in dairy ewes. J Dairy Sci 79 Suppl. 1, 234 [Abstract]

Naumann I, Fahr RD (2000) Investigation of milk flow from udder quarters. Arch Tierz 43, 431-40 [in German]

Niznikowski R, Popielarczyk D, Strzelec E, Wojtowski J, Dankow R, Pikul J, Goslawski W, Kuczynska B (2006) The effect of early colostrums collection on selected performance traits in sheep. Arch Tierz $49 \mathrm{SI}, 226-30$

Niznikowski R, Rant W, Sztych D, Radzik-Rant A, Kuznicka E (2001) The level of consumption milk production of Polish Lowland sheep depends on milking method. Arch Tierz 44 SI, 309-14

Norusis MJ (1993) SPSS for Windows: Base System Userss Guide. SPSS, Chicago

Nowak R, Murphy TM, Lindsay DR, Alster P, Andersson R, Uvnas-Moberg K (1997) Development of a preferential relationship with the mother by the newborn lamb: Importance of the sucking activity. Phys Behav 624, 681-8

Sandoval-Castro CA, Leaver JD, Anderson S (1995) Manejo de la nutrición y de la relación vaca-ternero. In: Conceptos y Metodologías en Fincas con Sistemas de Producción de Doble Propósito CIAT Publication No: 296, Cali, 45-66 [in Spanish]

Sallam SMA (2005) Effect of recombinant bovine somatotropin on sheep milk production, composition and some hemato-biochemical components. Small Rum Res 56, 165-71

Schakleton D, Haywood MJ (1985) Early mother-young interactions in California bighorn sheep. Ovis Canadensis Californiana. Can J Zool 63, 868-75

Scharch C, Süb R, Fah R (2000) Factors affecting milk traits and udder health. In: East Friesian milk sheep. Proc of 6th Dairy Sheep Symposium. Guelph, Ontario, 117-28

Snowder GD, Glimp HA (1991) Influence of breed, number of suckling lambs and stage of lactation on ewe milk production and lamb growth under range conditions. J Anim Sci 69, 923-30

Spinka M, Illman G, Algers B, Stetkova Z (1997) The role of nursing frequency in milk production in domestic pigs. J Anim Sci 75, 1223-8

Teh TH, Potchoiba MJ, Escobar EN, Lu CD (1987) Weaning methods of goat kids. J Dairy Sci 67, 137-8

Torres-Hernandez G, Hohenboken W (1980) Relationships between ewe milk production and composition and pre-weaning lamb weight gain. J Anim Sci 50, 597-603

Toukourou Y, Petes KJ (1999) Impact of feed restriction on the growth performance of goat kids. Arch Tierz 42, 281-93 [in German]

Volanis M, Kominakis A, Rogdakis E (2002) Genetic analysis of udder score and milk traits in test day records of Sfakia dairy ewes. Arch Tierz 45, 69-77 
Wojtowski J, Dankow R, Gut A, Pikul J, Slosarz P, Stanisz M, Steppa R (2001) Fatty acid composition and cholesterol content of sheep and goat milk fat during lactation. Arch Tierz $44 \mathrm{SI}, 299-308$ [in German]

Wojtowski J, Slosarz P, Bielinska S, Nowicki S, Gut A, Dankow R (2006) Ultrasound image of morphological changes of teat end in sheep caused by machine milking. Arch Tierz $49 \mathrm{SI}, 231-7$

Wolf J (2000) Housing of milking cows considering high milk yield. Arch Tierz 43 SI, $51-7$ [in German]

Received 30 July 2008, accepted 25 March 2009.

Corresponding author:

Assoc. Prof.Dr. MURAT CIMEN

email: mcimen@gop.edu.tr

Department of Animal Science, Agricultural Faculty, Gaziosmanpasa University, Tokat, Turkey 